\title{
'An Uphill Job Demanding Limitless Patience'. The Establishment of Trade Unions and the Conflicts of Development in Sudan, 1946-1952
}

\author{
Elena Vezzadini
}

\begin{abstract}
This chapter focuses on conflicts of development from the point of view of the entanglement between development, labour legislation, and labour conflicts during the time of decolonisation. It describes the origins of the trade union movement in Sudan, created after the Second World War, and covers the history of that movement up until 1952, the year in which its curve of radicalisation was stopped and it turned towards more conciliatory labour relations. Dwelling on internal sources emanating from the colonial government and the various labour attachés sent to Khartoum, the chapter aims to shed light on the reciprocal influences and feedback effect between the three main actors of these conflicts: the British government, whose agenda set colonial labour welfare as a top priority; a reluctant Sudanese government accustomed to decades of laissez-faire in matters of labour; and the workers, who quite suddenly discovered that they had the power to compel the government to listen to their demands.
\end{abstract}

\section{Introduction}

It is not enough to say that the Sudan is not capable of modern industrial development and should therefore be left alone. [...] It is certain that neither the world opinion nor a growing political consciousness in the Sudan itself will tolerate stagnation...; there must be, in the Sudan as elsewhere in the world, progress in standards of living, security, health,

* I wish to express my gratitude to Irene Bono and Béatrice Hibou for letting me embark on this project. I am grateful for their comments, and for those of Didier Peclard, Nadia Hachimi and the other participants of the workshop in Geneva on the 7-8 September 2015. 
education and generally in those humane practices which go by the name of civilisation. ${ }^{1}$

Trades Unions would have been premature [in Sudan, that is] predominantly an agricultural country ... Trade unions will not change the traditional 'Arab' contempt for manual labour; shop stewards and workers' committees will not make sense in the conditions which are permitted and encouraged by popular opinion and the teachings of Islam. ${ }^{2}$

These two quotes, the first taken from the report of a Foreign Office resident minister in Cairo on the labour situation in Sudan, dated 1944, and the second from notes written in 1946 by the Civil Secretary of Sudan, Robertson (the highest colonial authority after the Governor General), in response to London's recommendations to begin to form trade unions in Sudan, are fascinating glimpses into the conflict of visions as to which role to assign to the colonial state. The first maintained that the state had to provide for welfare and development for all. The second - in line with indirect rule - considered that state intervention had to be minimal because people were better governed by their own 'traditions', and thus that exogenous institutions such as trade unions should not be introduced. And yet, at the end of 1952, six years after Robertson had expressed such an opinion, there were as many as 99 registered trade unions in Sudan, representing an estimated 100,000 members.

This chapter will focus on the uncertainties, ambiguities and unpredictable outcomes spawned by conflicting visions of which role the state had to play in the lives of the colonised people, by studying one case in point - namely, the conflicts triggered by the new labour legislation of the late 1940s in Sudan. By choosing the theme of labour and development in the context of decolonisation, the author is aware that she is on a well-trodden path, in two ways. First, the connection between development and the elaboration of a system of workers' welfare (Cowen and Shenton, 1991 and 1996; Butler, 1999; Lewis, 2000; Havinden and Meredith, 2002; Burton, 2003; Constantine, 2005; Duffield and Hewitt, 2009; Seekings, 2011) and the political implications of labour conflicts in the era of decolonisation have received much scholarly attention (see for example Berman and Lonsdale, 1980; Freund, 1988; Shane 1989; Howe, 1993; Maul, 2012; Tijani, 2012; Teelucksingh, 2015); and all the more so following the

1 The National Archives of the UK (TNA): R. Peers, Labour in the Middle East: Sudan, Undated, 1944. Enclosed in Peers to Robertson, 22.7.1944, FO 921/305, p. 10.

2 The National Archives of the UK (TNA): Comments on Mr. Audsley's Notes on His Recent Visit to the Sudan, JW Robertson, Civil Secretary, undated, included in Robertson to Speight, Khartoum, 4.6.1946, LAB 13/479. 
influential studies of Frederick Cooper (to cite just a few: Cooper, 1992, 1996; Cooper and Packard, 1997). However, because of its atypical status as an AngloEgyptian condominium, Sudan is usually left out of such scholarship.

Yet, in spite of the lack of dialogue with the rest of the continent, there exists solid scholarship on labour in Sudan. Authors such as Fawzi, Sikainga, Cross and many others have explored in great detail several aspects of labour conflicts that occurred on the eve of independence (Fawzi, 1957; Sikainga, 1996 and 2002; Ali Taha, 1970; Cross, 1997; Curless, 2013). Such scholarship bears many resemblances to the angle of analysis chosen here: first because it focuses on the relations between labour, politics and the colonial state, and second because it mostly relies on the colonial archive. The primacy of colonial sources is not due to a lack of alternatives - such alternatives abound. Not only are many witnesses still alive, newspapers such as al-Saraha (Frankness in Arabic) and al-Shaab (the People), strongly sympathetic to the labour movement, reported on labour-related news for decades. ${ }^{3}$

Nevertheless, my choice here has been to mobilise colonial sources, because it is from these that the historian can perceive best the uncertainties, entanglements, and unintended feedback effects generated by the interaction between three main actors: London's Labour government, the Sudan colonial government and the workers' movement. In this way, this contribution aims to echo the main preoccupations of this special issue: the imbrication of development policies with stories of globalisation and market extension; the transformations of typologies of governmentality; the centrality of development in the formation of states, in particular in the context of decolonisation; and finally the fragmentizing impact of development plans, first as enacted by, and impressed upon, a multiplicity of actors with different aims, and second as entangled with social hierarchies and visions that the state had. Finally, the case of the conflicts triggered by the introduction of labour legislation in Sudan reveals how development plans were ridden with contradictions, between the universalism of their intentions, the implications of their norms - which carried a political, moral and emotional message about who were the 'right' actors, their 'right' attitudes and the modalities of the realisation of labour negotiations - and the discriminatory way in which these plans were eventually implemented on the ground.

Because Sudan studies have long suffered from insularity (Sharkey et al., 2015), I shall begin this chapter by inscribing development conflicts related to labour in Sudan into two entangled international stories, although narrated very sketchily: first, that of how British imperial development policy fostered

3 These newspapers can be found at the National Records Office, Khartoum. 
the creation of trade unions in the colonies; second, the story of circulation and mutual learning among radical labour movements, and in particular between those in Egypt and those in Sudan.

2

\section{Labour in Sudan, from Indirect Rule to the 1940 Colonial Welfare and Development Act}

The most important event of the political history of Britain in the first half of the twentieth century was probably the coming to power of the Labour Party. This happened following a century-long process of sharp societal conflicts around questions of labour. From the end of the nineteenth century, heterogeneous radical groups and militant workers that had been, until then, hostile to the formal political arena finally agreed to participate in institutional politics and came to be absorbed into a labour coalition that coalesced into the Labour Party, officially founded in 1900 . The party grew in strength and prestige, and became the main opponent of the Conservative Party, finally coming to power for the first time in 1924, and again in 1929-1931 (Howell, 1983). It was under the Labour party that the first act was passed concerning the duty of a government to develop its colonies not only economically, but also socially and politically - the British Colonial Development Act of 1929. The crisis of 1929 left this act a dead letter for a decade (Constantine, 2005, 141-166).

In 1935, severe labour agitations were carried out by the miners of the Copperbelt of northern Rhodesia, and between 1934 and 1939 the planters of the British West Indies went on strike. In the 1930s, while these mass strikes were occurring, the Labour Party remained in opposition. However, each of these episodes fed the party's struggle against the Tory government, providing them with arguments to use in harsh attacks on their Conservative adversaries (Thorpe, 1997). As a consequence, systematic denunciations in political debates of cases of exploitative colonialism kept the issue of colonial workers' welfare in the spotlight (Vickers, 2004; Worley, 2005; Corthorn and Davis, 2008).

Amid the struggles between the Conservatives and Labour was a third important actor-the Communist Party. The Labour Party was soon confronted with the problem of how to avoid the defection of its more radical wings to communism, especially in light of the fascination that Soviet Russia held among leftist circles (Lilleker, 2004). When the Labour Party eventually returned to power in 1946 (remaining in government until 1951), it adopted a policy of pulling out all the stops on welfare and of co-opting the larger trade unions, notably through the Trades Union Congress (TUC) (Orr, 1966; Hobsbawn, 1967; Ravier, 1981; Thorpe, 1998, 2000), also explicitly to counter communism. 
In the colonies too, trade unions and workers' welfare ordinances were introduced also to defuse the drive towards communism and radical anticolonialism. The administrators repeatedly noted the anti-colonial leanings of the strikers and the proximity between labour grievances and political radicalism. As Cooper and others have demonstrated in detail, it was in this context that the 1940 Colonial Development and Welfare Act was approved (Cooper, 1996). Development and the amelioration of the living conditions of workers, but also a solid labour legislation were meant to stop the drift towards anticolonial radicalism. Thus, one of the clauses of the Act stated that: 'no territory might receive aid under [the Act's] provision unless it had in force legislation protecting the rights of trade unions, and unless the works for which the aid was to be used were carried out under a contract that embodied a fair wages clause...' (Zeilig, 2009, 72). The Colonial and Foreign Offices were duly instructed to supervise its implementation in the colonies.

In Sudan, the government adopted the new directives with a certain delay. In 1946 a five-year development plan was launched, followed in 1951 by a second one, larger and more ambitious. ${ }^{4}$ The wording of the 1946 plan followed closely the guidelines of the colonial Act: to provide 'the raising of the standard of living of the population by increasing the national income and by the provision of additional social services, education particularly. ${ }^{5}$ In order to fully capture the novelty of this paradigm, it must be compared with native Sudanese policy prior to the 1940s. The country, an Anglo-Egyptian condominium from 1899 on, was governed by a hybrid rule of two countries with the majority of powers held by the British. After a short failed essay at integrating the educated elites into the government, and as a backlash against the nationalist uprising of 1924, the administration had turned wholeheartedly to indirect rule. Its core principles had clear economic implications, at least in theory: according to indirect rule, economic needs were shaped by local culture and traditions and thus were very limited, as Sudanese were not accustomed to global economy. In reality, the opposite was true: Gezira, an irrigated territory as large as Great Britain between the Blue and White Niles, was devoted to the growth of cotton for export, in a highly organised scheme run by the Gezira Plantation Syndicate (Gaitskell, 1959; Bernal, 1991). The government supervised closely the

4 The National Archives of the UK (TNA): Sudan Five-Years Development Plan, enclosed in Huddleston, Khartoum, to British Ambassador, Cairo, 17.2.1947, FO 371/63063. Sudan Government, Development Budget Estimates, 1951/56 Programme, 1st July 1951 to 3oth June 1952, Sudan Pamphlet 10, Sudan Library, University of Khartoum.

5 The National Archives of the Uк (TNA): Notes on the Expansion of Colonial Production, Memo No. 17, enclosure in Butters to Riches, Dover House, Whitehall, 25.8.1947, FO 371/63064. 
marketing of this commodity, and the same happened to other export products such as gum arabic, sesame and millet. ${ }^{6}$

The majority of state revenues were generated by agricultural exports, and depended on the mobilisation of a substantial labour force. Most salaried workers were employed either as farmhands, or in domains connected to trade, such as ports and railways. However, the scarcity of wage workers fostered high salaries (in comparison to living costs) during most of Sudan's colonial history. This made workers quite an assertive group, perhaps the best evidence of this being the frequency of strikes. From the beginning of the condominium, workers went on strike confidently, and often. ${ }^{7}$ It was common for employees to walk away from their employers in order to exert pressure for better conditions (be they salaries, food, lodging, or other improvements). On average, colonial administrators signalled a strike at least once per year. The strikes involved different categories of workers and geographical sites: for instance, employees of a ginnery at Sinkat, dockers at Port Sudan, tram drivers in Khartoum, Gezira cotton pickers, and so on. However, such strikes were dealt with locally and never generated country-wide debates. The local administration considered them to be spontaneous phenomena generated by the invisible hand of the market and by the 'laziness' of the Sudanese. More generally, the administration attempted to force certain specific categories of Sudanese into work (former slaves in particular (see Sikainga, 1996; Cross, 1997; Vezzadini, 2010), but with only limited success.

What is important to emphasise for the purpose of this chapter is that before the 1940 s workers were invisible to the eyes of the state, both as economic

6 How to control agricultural produce was vividly debated, as evidenced in the agenda and papers of the Board of Economic and Trade; see the following files: Civsec 1/53/144, Civsec 1/53/145, Civsec 1/53/146, and Civsec 1/54/147 (Khartoum: National Records Office).

7 A few examples will suffice: in 1908, government workers went on strike seeking better pay; in 1909, the government noted the occurrence of a strike in the Kamlin estate and another in the Fadlab agricultural scheme; in 1910 labourers supplied by the Central Labour Bureau refused to work at the wage offered; in 1912, a wave of strikes aimed at securing better working conditions involved dockers in Port Sudan. It is probable that further industrial action went unrecorded. Other strikes were overtly political: in 1919, a large strike involving railway employees (at the time they were mostly Egyptians, enrolled in a corps-supervised by the military — known as the Railways Battalion) occurred in Atbara in support of the Egyptian Revolution (Vezzadini, 2015). Similarly, during the 1924 revolution several strikes took place in Atbara, Khartoum and Port Sudan in protest against the arrest of the leaders of the revolt. As for the 1930s, after a period of economic depression the number of strikes rose again. Their pace is described by Cross (1997, 236); see also Sikainga (1996, 90-91) and Perkins (1993, $70-71)$. 
and as political actors. For instance, during the 1924 revolution the British believed that workers attended demonstrations because they were paid or manipulated to do so, and not because they had decided to attend (Vezzadini, 2015, 234-254). All this was to change drastically after the Second World War.

Against this backdrop of indirect rule and of the lack of concern for waged workers, the disposition to simultaneously introduce general development plans and a labour legislation — both steered from London-were truly a sign of a new era for Sudan. In 1946, the Labour Board (renamed the Labour Branch in 1949) was duly instructed to begin to work under the aegis of the Civil Secretary. That year, Edward H. Macintosh, a former Sudan Political Service employee, was appointed Labour Officer. In addition, in 1947 the Foreign Office sentfrom London-a labour expert, R. Brown, seconded directly from the Ministry of Labour, chosen because of his experience of the West Indian strikes; the same was the case for his successor, M.T. Cowan, who replaced Brown in April 1948, and who had been a labour advisor in Jamaica from 1945 to 1948 (Cross, 1997, 248). In 1949 the Foreign Office changed strategies and sent an independent syndicalist from the TUC, D. Newman, in harmony with the new line of involving the TUC in settling colonial labour disputes (Weiler, 1984; Cross, 1997, 248-249). In addition, the Sudanese government received at least three visits from Cairo from M.T. Audsley, a key figure of these years who was employed as labour counsellor at the British Embassy in Cairo and as Labour Adviser to the Middle East Office. His notes and reports include essential information on trade unions in Sudan. ${ }^{8}$

The number of envoys sent to advise the Sudanese government should not be missed, as it reveals the determination of London to supervise closely the labour question in the country. This level of involvement from the part of London on internal Sudanese affairs was a radical change for Sudan's government, which until then had enjoyed total freedom on matters relating to domestic policy.

The second story of entanglement I shall briefly discuss here is that of the labour movement in Sudan and the international workers' struggles in the

8 According to Beinin and Lockman $(1998,304)$, 'Audsley was the chief architect of postwar British labour policy in Egypt', who struggled 'to promote a non-political trade union movement.' His reports are: Note on Visit to the Sudan, 25th February to 15th March 1946; Note on Visit to the Sudan from 1oth to 2oth March 1947 inclusive, FO 371/63088; Notes concerning the Sudan Railway Strike, M. Audsley, Cairo, 26.4.1948, Fo 371/69235; Report on visit to the Sudan from 1st to 2oth February 1951 inclusive, FO 371/90299; all in the The National Archives of the UK (TNA). On the subject of Audsley, see also Labour Attache, Cairo, House of Commons Debate, 15 May 1950, vol. 475 (863-864), http://hansard.millbanksystems.com/commons/1950/ may/15/labour-attache-cairo (accessed on 21 August 2015). 
empires, beginning with the influence of the Egyptian labour movement. British officials noticed such connections early. The commission on living standards of 1948 maintained, for instance, that: 'The whole trend of world opinion is towards raising the wages and standard of living of the worker and the Sudanese worker does not intend to be left behind in this movement....9 While the Second World War was raging in North Africa, information on trade unionism came to Sudan through various channels. There was, of course, British propaganda: as the historian Fawzi recounts, people came to know about trade unionism 'in response... to the British Ministry of Information war pamphlets about the British way of life, one of which, on trade unionism, had been the subject of study by a discussion circle in the Atbara Technical school Old Boys Club' (Fawzi, 1957, 38). As mentioned previously, from 1950 on, dedicated newspapers such as al-Saraha and al-Shaab carried news about international labour developments. In this sense they filled a gap, as the main Sudanese newspapers, such as al-Ray al-Amm or al-Nil usually did not cover such news. However, Sudanese most probably read about labour struggles even earlier through the Egyptian press.

Al-Saraha and al-Shaab watched the workers' movement in Egypt very closely and exposed their readers to its communist, anti-imperialist language. Labour conflicts shook Egypt from the late 1930s through the 1940s (Vatikiotis, 1969, 337-342; Beinin and Lockman, 1998). The scope of this chapter only permits me to highlight the most salient of these events here. In 1932, a mission from the International Labour Organization exposed the scandal of the labour situation in Egypt, where most industries imposed fourteen to sixteen daily working hours, employed children, and ignored the most elementary forms of worker protection (Beinin and Lockman, 1998, 204-205). The introduction of worker protection measures advanced sluggishly, and strikes took place incessantly amidst difficult economic conditions connected to the 1929 crisis, with a government in constant oscillation between labour reforms and repression. For instance, in 1938 a general strike at one of the largest textile factories in Egypt, al-Mahalla al-Kubra, was violently repressed. In 1939, the leaders of the General Federation of Labour Unions staged a three-day hunger strike, highly popular and widely covered by the press. When martial law was imposed on the country because of the war, tramway workers challenged the decision, launching a strike in March 1940. In 1942, finally, the government officially recognised the syndicates and passed trade union legislation. More strikes were to follow after the war. In 1946 for instance, Egyptian industrial workers of the

9 The National Archives of the UK (TNA): Report of the Independent Committee of Enquiry, Khartoum, 14.4.1948, FO 371/69235, p. 13. 
major textile industries walked out en masse, followed again by the tramway workers. Even the police, in Cairo and Alexandria, went on strike in 1948.

The political impact of Egyptian labour struggles on Sudan should not be overlooked. As with many other junctures in Sudanese colonial history, Egyptian anti-colonial nationalism was a powerful inspiration for the Sudanese. In Sudan, Egypt had historically played the role of a counterweight to British colonisation (Abdel-Rahim, 1969; Beshir, 1974; Warburg, 1978; al-Safi, 1989). For the Ashiqqa, the most important pro-Egyptian party in Sudan (yet connected to the largest Sudanese Sufi brotherhood, the Khatmiyya), unity with Egypt was a synonym of liberation from colonialism. But for Sudanese workers there was another reason for their closeness to Egypt: Egyptian workers were struggling against the dominant classes as much as against British economic colonisation. Like them, the Sudanese were waging a double war against the British: first as their colonisers, and second as their managers. In fact, the colonial government was the country's largest employer and manager of the economic system.

\section{The Workers Affairs Association and the Beginning of} Trade Unionism

As already mentioned, in June 1946 Civil Secretary Robertson stated that there was no scope for creating trade unions in Sudan. And yet, in July 1946, some Sudan Railways craftsmen founded the Workers Affairs Association (WAA) in the city of Atbara - home to the headquarters of the Sudan Railways Department. The association was headed by Sulayman Musa, and al-Tayyib Hassan al-Tayyib. The two were no hotheads: quite the contrary, they were two artisans with long careers behind them as permanent employees of Sudan Railways (Curless, 2013, 806). ${ }^{10}$ The association was founded at the beginning to provide for social support (Fawzi, 1957, 38-39). As Cross notes, its statute made no reference to the strike as a weapon, excluded any political aims, and reassured the reader that the WAA would take 'meticulous care to avoid any action likely to cause the management any inconvenience or trouble' (quoted in Cross, 1997, 241).

Simultaneously, the colonial Sudan Labour Board attempted to form Works Committees. These were to function as a link between employers and employees. In the words of the Civil Secretary, they represented a way for 'the artisan

10 The first was a supervisor, employed since 1926, and the second a pattern maker, employed since 1928 (Sikainga, 2002, 105). 
and labouring classes' to 'take an intelligent and constructive interest in the internal running of their business or department' (Fawzi 1957, 26-27).$^{11}$ However, the committees had no power to advise on matters directly connected to industrial relations, such as salaries and terms of service, matters that instead the WAA wanted to debate. In August 1946, the WAA asked to be recognised. The government refused on the grounds that the association was not adapted to such a role; but the WAA did not let the issue rest. Following one entire year of fruitless talks, the WAA decided to instruct all railway employees to stop work. The extent of the strike and its success made it an immensely popular event. From 17 to 23 July, the railway system was paralyzed. ${ }^{12}$ People throughout the country supported the activists in many ways, including by sending food ( $\mathrm{Si}$ kainga, 2002, 107-108). Eventually, the WAA succeeded in being recognised as the representative voice of railways workers.

Following on from this victory, the association confidently began to work on labour conditions. In October, it formulated demands that included an increase in salaries, annual leave for all workers, and the reduction of working hours. ${ }^{13}$ These demands were sent to railways management, but with the request that they be forwarded to Khartoum, thus expressing the idea that labour negotiations were a governmental responsibility. The Sudanese government gave a cold welcome to the demands, considering as 'extravagant claims' the WAA proposal for a pay increase of between 25 and 40 per cent. ${ }^{14}$ However, it responded by raising the minimum basic wage and promised the establishment of an independent committee of British and Sudanese experts to enquire into the situation of the railway workers. In January 1948, the commission had not yet begun its work, but by now the WAA had understood the power of the strike as a weapon. A second general strike of railway workers was launched for 26-28 January, and a third, 'indefinite' strike on 16 March. ${ }^{15}$ On 4 April, Sulayman Musa was arrested and charged with having given a highly seditious

11 Civil Secretary's Circular No. CS/37, 19.8.1946, quoted in Fawzi (1957, 26-27).

12 The National Archives of the UK (TNA): Correspondence about the strike is included in Fo 371/63088. For a detailed account, see Sikainga (2002, 105-107).

13 The National Archives of the U K (TNA): Strikes of Railway Workers in the Sudan, Fo Minute, 23.3.1948, Fo 371/69235.

14 The National Archives of the UK (TNA): Governor General of the Sudan, Khartoum to Foreign Office, London, 29.1.1948 (repeated for information to Cairo), FO 371/69235.

15 The National Archives of the UK (TNA): The third strike was launched because the deadline announced by the government to publish the findings of the independent committee had not been respected. Sudan Government, Sudan Railways' Employees, Report of the Independent Committee of Enquiry, Establishment Branch, Khartoum, 14.4.1948, FO $371 / 69235$. 
speech' at the Atbara mosque. ${ }^{16}$ The sentence pushed the workers to extend the strike to include the first two weeks of April. Finally, Musa was given a fine, and was released on April 17. The strike ended on the following day, on his instructions.

It is worth pausing a moment to reflect on why the government gave up its plans so quickly and recognised the wAA. It is possible to identify two main reasons: first, the dire conditions of salaried workers; second, London's injunction to develop labour regulation.

Indeed, from the beginning of the Second World War on, Sudan had been experiencing an economic boom. With the outbreak of the Korean War removing Korean cotton from the market, the price of Sudanese cotton soared. Government revenues multiplied spectacularly, tenfold from 1939 to 1951, and the country was awash with cash. So much cash, however, triggered unprecedented inflation. ${ }^{17}$ The evolution of the cost of living index is eloquent: considering 1938 as 100, the index soared to 170 in 1945, 229 in 1947, and 307 in 1949 (Fawzi, 1957, 22; Daly, 2002, 312-313). ${ }^{18}$ The redistribution of such cash was uneven: after the war, a drought that hit the north provoked famine conditions in some rural areas, and grain had to be imported from abroad. Against this backdrop of extreme inflation, the independent committee of 1948, enquiring into the plight of the railways workers, did not note any severe signs of malnutrition or illness. ${ }^{19}$ It did, however, underline that the workers' conditions were as bad as anywhere else in Sudan, and had never been good. ${ }^{20}$ Everywhere, in urban, working-class areas sanitary conditions were dire, lacking even the most basic

16 The National Archives of the UK (TNA): Telegram from Dakhlia, Khartoum, to Sudanology, London, 4.4.1948, FO 371/69235.

17 To counter inflation, the government tried to protect at least its own employees by issuing special bonuses, called Cost of Living Allowances. These were increased every year and could be quite sizeable. In 1947 for example, they stood at 70 per cent of a salary. The WAA still considered such bonuses to be inadequately matched to the cost of living.

18 Daly reports that at the end of 1948, dhurra (millet), the cereal used as a staple food by Sudanese families had risen to a price 736 per cent higher than its price in 1938 (Daly, 2003, 302-303).

19 'Statistics provided by the Medical Authorities for hospital admissions do not reveal that there exist in Atbara any industrial diseases directly due to conditions of work or to bad housing or sanitation... The Medical Authorities have no evidence to show that railway workers are suffering from malnutrition or an inadequate diet'. The National Archives of the U K (TNA): Report of the Independent Committee of Enquiry, Khartoum, 14.4.1948, FO 371/69235, p. 11.

20 The National Archives of the UK (TNA): Report of the Independent Committee of Enquiry, Khartoum, 14.4.1948, FO 371/69235, p. 14. 
services (Fawzi, 1955; Lewis, 1962; Perkins, 1993, 99-122; Sikainga, 1996, 73-95 and 149-183). From the government's perspective, any refusal to improve such a debasing environment was deemed impossible in the framework of the London directives, which — as we have seen-had made improvements in working conditions a precondition of development funding. Thus, Khartoum had no choice but to listen carefully to the demands for reform put forward by the workers.

But the divergence of opinion between London and Khartoum was only barely concealed. Bevin, Secretary of State at the Foreign Office, accused the Sudanese government of not keeping up with the new ideas about development and labour, while others in London considered the government as outright reactionary. ${ }^{21}$ Thus, it fell to the labour officers, people like Audsley and Brown, to mediate between these two visions and find a consensual narrative that would work on the ground. So, for example, in April 1948 Audsley provided the Sudanese Government with a functional way of interpreting the WAA strike. He blamed the association, but with certain reservations:

[The leaders of the WAA] ... have had no experience of collective bargaining and negotiation and there is an absence of tact, calmness in debate and discretion in argument; their oriental political mindedness and practice weight against them regarding, to us, normal Trade Union behaviour. $^{22}$

Therefore-Audsley went on-the duty of the government was not only to elaborate legislation, but also to teach its counterparts how to negotiate: 'A heavy responsibility rests upon these officials to prepare the Sudanese for industrial self-government...'. Meanwhile, he was also suggesting how British officers should set their own emotional tone: trade unionists had to be treated 'with patience and helpful encouragement by the British officials. ${ }^{23}$ This discursive repertoire is widely present in the sources. Another report on trade unions admonished British officers to attend to 'the tender plant of mutual

21 The National Archives of the UK (TNA): Minute to Atlee, 7.7.1947, FO 371/62557, NA, quoted in Cross $(1997,246)$; Notes concerning the Sudan Railway Strike, M. Audsley, Cairo, 26.4.1948, FO 371/69235.

22 The National Archives of the UK (TNA): Notes concerning the Sudan Railway Strike, M. Audsley, Cairo, 26.4.1948, Fo 371/69235, p. 3.

23

Ibid. 
confidence. ${ }^{24}$ Cowan, the labour officer that followed Brown, expressed this concept eloquently: 'It is going to be an uphill job demanding limitless patience on the part of all British officials, who are being constantly reminded that they are the representatives of an alien Government.'25

A tangible example of how labour attachés managed to reconcile Sudan's administrators hostile to the new labour directives is the framing of the new Trade Union Ordinance in 1948 by R. Brown. A civil servant with extensive experience in labour conflicts, Brown perceptively understood that the Sudanese government had to be given some safeguards. While being almost a word-forword copy of the nineteenth century British Trade Union Act, the ordinance contained one fundamental difference: in order to be recognised, trade unions had to register, and to do so, they had to draft their statutes and submit them to a Registrar of Trade Unions, which would examine them, and approve-or not - the union. Despite this, Brown was more sympathetic than others to Sudanese labour, and worked hard to convince the government to adopt a conciliatory approach. ${ }^{26}$

Nevertheless, if one compares government statements with regard to labour and these statements' concretisation on the ground, a great discrepancy clearly emerges. When disincarnated and disembodied, the demands of the workers were deemed to be just and reasonable. Documents show, unmistakeably, a consensus among government officials that the situation of Sudanese workers had to be improved. And yet, the incarnations of the labour movementincluding Sulayman Musa and, later, two other famous trade unionists, al-Shafi Ahmad al-Shaykh and Muhammad al-Sayyid Sallam — were systematically harassed and their statements criminalised. All spent quite some time in prison, and all were portrayed as opportunists pursuing personal gain. When the new Trade Union Ordinance was issued in late $1948,{ }^{27}$ for example, the wAA bitterly

24 The National Archives of the UK (TNA): Development of Trade Unions in Sudan, undated, unsigned, included in Robertson to Allen, 1.11.1950, LAB 13/480.

25 The National Archives of the UK (TNA): Cowan to Gee, Civil Secretary Office, Khartoum, 15.2.1949, LAB 13/480.

26 The National Archives of the UK (TNA): '[we must] avoid giving any impression that Government is out either to break up the WAA or 'victimise' its leaders... so that there can be no question of allegations that Government is using its powers as such, in furtherance of its interests as the employer.' The Threatened 'Indefinite' Strike of the Railways, R. Brown, 4.3.1948, FO 371/69235.

27 The National Archives of the UK (TNA): The ordinance was issued together with a set of new labour laws: the Employers and Employed Persons (Amendment) Ordinance, the Workman's Compensation Ordinance, the Regulation of Trade Disputes Ordinance, 
criticised it. ${ }^{28}$ In the opinion of Cowan, this criticism was driven by the personal agendas of WAA leaders:

When all is said and done, the WAA have two objections to the Ordinance, unexpressed, but none the less real. These are -

1- It gives freedom to all to organise and WAA 'leadership' will in due course be challenged.

2- They will have to account for their funds by responsible audit, whereas last year a substantial balance of some thousands of pounds sent down from Cairo quietly disappeared. ${ }^{29}$

In other words, for Cowan, the wAA leadership opposed the ordinance because they were corrupt and power-hungry. But there was more: they had been 'inoculated' by communism, a fact that—for Cowan — was 'amply confirmed by our meeting with them, and by the propaganda they issue. ${ }^{30}$

Demonstrators suffered similar harassment. Demonstrations would typically take place after a strike, or in protest against the arrest of a union leader, and often ended with injuries to the participants. For example, during the strike of July 1947 a crowd of around 1,00o people marched to the office of the General Manager of the Railways; ${ }^{31}$ riots followed and dozens were hurt during clashes with the police. The army was sent in and 57 participants were arrested. During the strike of March-April 1948, when news of the arrest of Sulayman Musa spread, a series of demonstrations took place in Khartoum, Port Sudan and Atbara. Khartoum was the largest of these, attracting between five and six thousand people. Here too, the police was sent in, tear gas used, and people wounded, 59 being arrested. ${ }^{32}$ Such episodes were frequent.

What were the results of this ambiguity between disembodied government fantasies regarding the patient taming of childlike labour militants, the

and the Workshop and Factories Ordinance. Most of this legislation can be found at FO $371 / 69235$

28 The National Archives of the UK (TNA): Cowan to Gee, Civil Secretary Office, Khartoum, 15.2.1949, LAB 13/480.

29 The National Archives of the UK (TNA): Cowan to Gee, Civil Secretary Office, Khartoum, 15.2.1949, LAB 13/480.

30 The National Archives of the UK (TNA): Cowan to Gee, Civil Secretary Office, Khartoum, 15.2.1949, LAB 13/480.

31 Sikainga $(2002,106)$ gives a figure of 5,000 demonstrators.

32 The National Archives of the UK (TNA): Telegram from Dakhlia, Khartoum, to Sudanology, London, 15.4.1948, FO 371/69235, NA. Telegram from Khartoum, unsigned, to Sudanology, London, 14.4.1948, FO 371/69235. 
physical repression of the workers - and, in particular, their leaders - and the important concessions made to the labour movement? This oscillatory pattern shaped the peculiar form of the labour struggles of the time. First, the workers' movement began to make systematic use of strikes, because it had learnt that strikes worked. The WAA went on strike in order to be recognised in the first place, and then to increase wages and to protest against the existing trade union regulations; they got it all, even if with certain reservations. Indeed, when in $195^{2}$ the workers' movement broke down, it was not because strikes had lost their effect, but because the workers refused to go on strike. Second, the violent oppression of the government against the workers' leaders generated a strong wave of popular sympathy, a wave which transcended social strata. For the workers' movement, this lent strength and legitimacy to its strategy of confrontation. For the colonial administration, such punctual violence neutralised and defused the image that the government was patiently trying to build for itself—as a development provider and benefactor of all workers.

\section{$4 \quad$ 'No bargaining with Employer, no Exemptions from Strikes' ${ }^{33}$}

Even if, by 1949, the WAA had learnt of the power of the strike and spoke a language that was more confrontational than that of 1946, its leaders limited themselves to discussions about labour and kept politics out. And it was from 1949 that trade unions spread like wildfire among wage workers, for reasons that still remain unclear. The numbers are eloquent. After the promulgation of the Trade Union Ordinance at the end of 1948, the registration of new unions began. Their numbers rose from five in 1949, to 42 at the end of September 1950, and to 99 in $1952 .{ }^{34}$ In March 1949, the WAA broke into two different organisations: the Sudan Railways Trade Union, which — by 1951—had 19,00o members and was by far the most powerful union in Sudan, and the Workers' Congress, an umbrella organisation federating all unions, even if the government never recognised it officially. ${ }^{35}$

The British viewed the Workers' Congress as a more moderate organ than the WAA. The government found it easier to negotiate with it, and at the end

33 The National Archives of the UK (TNA): Sudan Political Intelligence Summary, December 1951, FO 371/96846.

34 The National Archives of the UK (TNA): Development of Trade Unions in Sudan, undated, unsigned, included in Robertson to Allen, 1.11.1950, LAB 13/480, and Fawzi (1957, 92).

35 Ibid.: 'There is no special provision in the Trade Union Ordinance for the registration of federations of unions.' 
of $195^{\circ}$ its assessment was that it 'had on several occasion exercised a wise and restraining influence. ${ }^{36}$ Indeed, when the congress's first elections were held, neither Sulayman Musa nor al-Tayyib Hassan al-Tayyib presented themselves as candidates (they were also close to pensionable age), and only four out of the 15 original leaders of the WAA were re-elected. The role of the congress as an umbrella organisation whose leaders were trained to defend small unions was essential to the spread of unionism. Indeed, the number of unionised Sudanese in relation to the overall number of waged workers-in spite of the uncertainties inherent in such a calculation-is spectacular. In 1951, the number of union members was estimated to be between 70,000 and 120,000, set against a total number of salaried, urban workers estimated to be between 150,000 and 200,000. ${ }^{37}$ By comparison, in Egypt in 1944 there were 350 registered unions with an estimated total membership of 120,00o (Beining and Lockman, 1998, 293), but Egypt had twice the number of inhabitants and was much more industrialised. ${ }^{38}$ A list of registered Sudanese trade unions compiled in ${ }^{1951}$ included workers from the private and public sectors, and more specifically elementary school teachers, employees of the Sudan Post and Telegraph, bakers, tailors and domestic servants, and the staff of private companies such as the Gellatly and Hankey (the main shipping company of Port Sudan) or Shell. ${ }^{39}$

In spite of the higher opinion that those in colonial ranks had of the Workers' Congress, the number of strikes and workdays lost increased. In January 1950, the Workers' Congress asked for a 75 per cent increase in basic salaries, a request defined by Robertson as 'quite fantastic'. 40 As their demands were not met, the Sudan Railways Trade Union took the initiative and organised a threeday strike (5-7 March). In some places, including Khartoum, the call to strike was supported by 100 per cent of the workforce. ${ }^{41}$ Smaller unions launched numerous other strikes. On 23 April, the workers of the Medical Dressers Union went on strike - to secure their demands for eight-hour shifts—and so did,

36 The National Archives of the U K (TNA): Development of Trade Unions in Sudan, undated, unsigned, in Robertson to Allen, 1.11.1950, LAB 13/480.

37 Ibid. Note, however, that the census of 1956 estimates the number of urban, waged workers to be 350,000; quoted in Cross $(1997,245)$.

38 The National Archives of the UK (TNA): See also-FO 371/41380: Labour and trade unions in Egypt, and FO 371/41379, Labour and the Trade Union Question.

The National Archives of the UK (TNA): Note on Trade Unionism in Sudan, D.H.J. Newman, Trade Union Adviser, Khartoum, 26.4.1951, LAB 13/480.

40 The National Archives of the U K (TNA): Mayall to Allen, African Department, FO, London, 3.3.1950, FO 371/80607.

41 The National Archives of the UK (TNA): Telegram from Dakhlia, Khartoum, to Sudanology, London, 6.3.1950, FO 371/80607. 
on the same day, the Workers Union of the Sudan Light and Power Company. In October the medical dressers went on strike again. It is to be noted that in all such cases the unions opted for strike even before attempting to negotiate. ${ }^{42}$ Another general strike, from 5 to 8 August 1950, was organised in protest against a resolution passed in May by the Legislative Assembly—a Sudanese institutional organ set up to frame the steps that would take Sudan towards self-determination - for an increase in salaries and cost of living allowances that was judged inadequate. And yet, in November, Robertson still could assess the situation as 'not wholly unsatisfactory.43 $\mathrm{He}$, like many others, was convinced that such strikes were a necessary step along the way of learning how to conduct 'right' labour negotiations.

New elections at the Workers' Congress consigned such hopes to bitter disappointment. Between 15 and 21 November, 160 delegates of 48 unions elected two individuals considered to have radical leanings - namely, Muhammad alSayyid Sallam as president and al-Shafi Ahmad al-Shaykh as secretary. They were described as 'extremists using the Communist jargon'.44 Al-Shaykh had been a member of the WAA steering committee, and he was the general secretary of the Sudan Railways Trade Union. ${ }^{45}$ The Workers' Congress moved its headquarters from Atbara to Khartoum and changed its name to the Sudan Workers Trade Union Federation (sWTU F) (Fawzi, 1957, 103; Daly, 2002, 323).

With the SWTUF, the language of labour rights merged, to an unprecedented degree, with anti-colonial, communist and pro-Egyptian discourses. Even for the labour advisor Audsley, who had several times defended the labour movement, the turn taken by the swTUF represented 'an ominous development,' due to both the communist leanings of its leaders and the dictatorial tendencies of the federation, the leaders of which were ready to use their 'power as they thought it fit. ${ }^{\prime 6}$ The actions of the sWTUF matched its radicalisation. While limits to the scope of this chapter make it impossible to describe here all the events of the period, outlining just a few should clearly illustrate this transformation. The new leadership immediately passed a resolution in

42 The National Archives of the UK (TNA): Telegram from Governor of Khartoum to all Heads of Department, Sudan Agent in London, Sudan Agent in Cairo, 22.4.1950, FO 371/806o7.

43 The National Archives of the UK (TNA): Robertson to Allen, Khartoum, 1.11.1950, FO 371/80607.

44 The National Archives of the UK (TNA): Development of Trade Unions in Sudan, undated, unsigned, in Robertson to Allen, 1.11.1950, LAB 13/480.

45 Al-Shafi Ahmad al-Shaykh would be hanged by the Nimeiri regime in 1971 along with two other communist leaders of the swTUF, Abd al-Khaliq Mahjoub and Joseph Garang.

46 The National Archives of the UK (TNA): Audsley, Report on visit to the Sudan from 1st to 2oth February 1951 inclusive, FO 371/90299. 
which they threatened a general strike unless the government revoked both an anti-communist decree (the Defence of the Sudan Ordinance) that appeared to be tailored against trade unions, and the expulsion of the students of Khor Taggat—a secondary school near El Obeid. ${ }^{47}$ The students had been expelled en bloc because they had gone on strike to protest against the bad conditions at the school, but in reality the government suspected that they were being 'infected' by communist teachers. ${ }^{48}$ The link between Khor Taggat, the swTUF and the former's communist sympathies was disturbing for the government. While negotiations continued back and forth between the government and the SWTUF, at the end of 1950 railway firemen ${ }^{49}$ went on indefinite strike in protest against their working conditions. ${ }^{50}$ The limitless patience' of colonial officers had, by then, almost been used up. Audsley, who at the beginning of $195^{1}$ travelled to Khartoum once more, stated: 'Government continued its patient attitude but dealt firmly with the threats ... [These threats] were withdrawn but veiled warnings ... [were given] ... as to what the Government could expect if the demands of the workers ... were not conceded. ${ }^{51}$ Dealing 'firmly with the threats' meant once again arresting the leaders: at the end of December, the Railways Management charged five railways union members and al-Shafi Ahmad al-Shaykh with 'defamation'. They were tried and found guilty, and on the day of the sentence, railway workers called a sudden three-day general strike (27 to 30 December), although the call was not backed by the federation as it did not respect the 15 days of notice required..$^{52}$ In total, $5^{2}$ railway workers were arrested, even if they were quickly released.

47 The National Archives of the UK (TNA): The protest of the students of Khor Taggat was fully covered by the press (see, for instance, the following issues of al-Shaab: 12, 20 and 27 January 1951). In English: Political Intelligence Summary, January-February 1951, FO 371/90108. Secondary literature on the strike is scarce, but see Daly $(2002,346)$. In total, 76 of the 119 boys expelled were later readmitted to the school.

48 The National Archives of the UK (TNA): The strike was covered by the leftist newspaper al-Saraha, issues of 3, 8, and 14 December 1951. It was also described in the Sudan Political Intelligence Summary, November-December 1950, FO 371/90108, and covered generally in FO 317/90229.

49 Stokers tending the fireboxes of locomotives.

5o The strike was fully covered in the Weekly Press Reviews of December 1950 (Khartoum: National Records Office).

$5^{1}$ The National Archives of the UK (TNA): Audsley, Report on visit to the Sudan from 1st to 2oth February 1951 inclusive, FO 371/90299.

52 The National Archives of the U K (TNA): Sudan Political Intelligence Summary, JanuaryFebruary 1951, FO 371/90108. 
And yet, it was exactly at this moment that several unions under the umbrella of the swTuF began feeling uncomfortable with the federation's strategy. Two general strikes were called in three months - the first on 17 February and the second on 23 April 1951 - both demanding that the government deliver the usual 75 per cent increase in salaries. However, the first strike was described by the British as 'unpopular'53 creating severe tensions within the federation as many unions were against it, ${ }^{54}$ while with regards to the second, 20 unions out of 43 bluntly refused to participate in the proposed industrial action. ${ }^{55}$ This gave the government hope that the obdurate strategy pursued by the SWTUF was losing ground and that finally moderate forces were raising their heads.

In the following months, the same pattern repeated itself: the government exerted force not on trade unions as a whole, but on specific individuals; it was 'firm' with the heads and 'patient' with the members. Yet, this attitude led only to further mass protests. And the popular support generated for the federation as a reaction to government harassment further fuelled the SWTUF's drive to radicalism, without the federation realising that its members were apparently not ready to follow it in its politicisation.

In June 1951, the police went on strike (usually referred to as mutiny). The strike has been discussed in detail elsewhere (Berridge, 2011), and here it suffices to mention that it became, for the government, a pretext for arresting the 'communist' leaders of the SWTUF-Muhammad al-Sayyid Sallam and al-Shafi Ahmad al-Shaykh-despite the fact that they had not been involved in the decision to strike or its implementation. Their imprisonment on dubious charges triggered a new wave of popular protests. The SWTUF organised a general strike from August 26 to 29, supported by two-thirds of the unions. In Khartoum the workers staged a silent protest, holding 'placards carrying "Long live the struggle of the workers"' 56 This demonstration was momentous also for its female participation, even a British telegram noting 'Nurses at Khartoum

53 The National Archives of the UK (TNA): Trade Union in the Sudan, Allegations by the World Federation of Trade Union (Draft), included in Secretariat, Khartoum to African Department, London, 26.10.1951, FO 371/90230.

54 The National Archives of the UK (TNA): Audsley, Report on visit to the Sudan from 1st to 2oth February 1951 inclusive, FO 371/90299.

55 The National Archives of the UK (TNA): According to an intelligence report, the Executive Committee of the sWTUF tried several times in May to pass resolutions regarding strikes, but these resolutions were defeated. Sudan Political Intelligence Summary, May June 1951, FO 371/90109.

56 The National Archives of the uk (TNA): Sudan Political Intelligence Summary, JulyAugust 1951, FO 371/90109. 
hospitals took part in the demonstrations. This is the first time in the history of the Sudan that women have taken part in public demonstrations. ${ }^{27}$

By December 1951, the political radicalisation of the SWTUF was complete. At the elections held between 16 and 21 December, the two arrested leaders were reappointed in absentia, and the federation adopted a new constitutionvoted on by its members - the summary of which is worth quoting at some length:

Conference amended the constitution of the federation to permit political activities and announced its programme as immediate termination of all forms of imperialism in Sudan and reservation of right of selfdetermination. The means of achievement were to be non-cooperation with any form of imperialism and formation of a common front with political organisations having similar objects ... The demand for a general $75 \%$ increase in all wages was reiterated and it was decided to stage a series of general strikes, one three-day, one four-day, one five-days, each separated by a fifteen day interval. ${ }^{58}$

Such statues explicitly contravened the Trade Union Ordinance-notably the clause on political activities. They convey the message that the scope of the federation was now the struggle against 'imperialism', a struggle to be pursued by means of strikes. This attitude was best expressed by the new motto of the federation: 'No negotiation and the strike the only weapon. ${ }^{59}$ At this juncture, the federation was incarnating possibly the worst-case scenario for the British, and indeed had become the opposite of what they had intended it to be: rather than being instruments of development, created to ensure the general betterment of society by teaching workers how to defend their interests and be good producers, unions had become political organs in the hands of a virulent, communist-inspired anti-colonial crew, who moreover saw development as a imperialistic ruse.

In early 1952, the federation began to apply its strategy of head-on confrontation by calling repeated, short general strikes. The first was called from 20 to 23 January, and was fully observed by all the unions. The second was called on

57 The National Archives of the UK (TNA): For details of the female nurses' demonstrationciphered message entitled: First Women Demonstrators, FO 371/90230.

$5^{8}$ The National Archives of the U K (TNA): From Governor General, Khartoum, to Foreign Office, London, 20.12.1951, FO 371/90230.

59 The National Archives of the U K (TNA): Sudan Political Intelligence Summary, September 1951, FO 371/90109. 
23 March, and again was 'observed by nearly all government employees', even if it was noted that it enjoyed less public sympathy. ${ }^{60}$ But when it came to the third strike things went wrong. Muhammad Sayyid Sallam was finally released from prison on 3 April, only to be arrested again on the charge of giving an inflammatory anti-colonial speech. Immediately the sWTUF called for a general strike of an unlimited duration, to begin on 28 April. However, the Railways Union flatly refused to participate since the 15 -day notice period had not been respected. The federation considered that there was no need to comply with the requirements of an imperialist ordinance, but not all the unions shared this position. That the sWTUF seemed to have lost contact with the workers was also confirmed by further evidence: first, the strike had been called just before payday, meaning that the workers did not have the funds necessary to sustain an indefinite strike; second, the federation's leaders had not consulted anyone before calling the strike - a fact that was deeply resented. Grudges with regard to the undemocratic tendencies of the federation had been around for a while, and the government had been careful to nurture them. Also, since the radicalisation of the federation had begun, the government had shrewdly courted a potential opposition element. For example, the arrest of Muhammad Sayyid Sallam, who was also the head of the Railways Union, opened the way for the election of 'Abdallah Bashir, who was known both for his anticommunism and for his mild sympathies for the federation' ${ }^{61}$

The strike of 28 April went ahead nevertheless. In retaliation, the police immediately arrested 12 members of the federation and carried out house-tohouse searches during which communist literature was allegedly found. This time, the colonial government did not hesitate to apply a heavy hand, broadcasting a message in which it threatened that anyone who was not at work on the symbolic date of 1 May would be fired. By 30 April, the strike was over. On 11 May, a further 17 members of the federation were arrested, of which 11 were sentenced to one-year jail terms. The failure of the strike coincided with the rise of moderate forces among the unions, and the re-centring of the discussion on labour negotiations. ${ }^{62}$ More importantly, following Najib's coup d'état in Egypt in 1952, it became clear that Sudan would imminently gain its freedom. The politicians preparing the government of national liberation asked

\footnotetext{
6o The National Archives of the UK (TNA): Sudan Political Intelligence Summary, MarchApril 1952, FO 371/96846.

61 See, for instance, The National Archives of the UK (TNA): Political Intelligence Summary, September 1951, FO 371/90109.

62 The National Archives of the UK (TNA): Sudan Political Intelligence Summary, May-June 1952, FO 371/102701.
} 
the workers to collaborate and to suspend industrial action, and so they did, remaining mostly silent during the process of self-determination between 1953 and 1956.

The last point I wish to analyse here, by way of a conclusion, is a sketchy close-up of the SWTUF's communism. It is important to note that while there is a tendency in the literature to conflate workers' movements and communism, their stories do not coincide. The historian Nuri El-Amin (1986, 1987, 1989, 1996a, 1996b, 1996c, 1997) has demonstrated at great length the influence of communism on intellectuals and secondary school students. However, this section of the population was quite different to that of salaried manual workers. The difference was not necessarily based on literacy-highly skilled artisans were literate-but rather on corporate identities and socio-professional categories. The founders and leaders of Sudan's first communist organisations (such as the Sudan Movement of National Liberation, or SMNL) were from the educated elite and not from the rank and file of the SWTUF. ${ }^{63}$ In the first trial in Sudan of individuals accused of communism under the Defence of the Sudan Ordinance, in April 1951, 21 people faced charges; six were acquitted. One of those released was Muhammad al-Sayyid Sallam, president of the SWTUF-as it was impossible to prove that he belonged to the Communist party. ${ }^{64}$ Other union leaders, instead, such as al-Shafi Ahmad al-Shaykh and Qasim Amin were, admittedly, communists. They had turned to communism, however, more because they were militant anti-colonialists than for a close adherence to a Marxist ideology. In the communist-inspired party they found a framework sufficiently radical and uncompromising to fit their views (Cross, 1997).

A remark of 1951 by Robertson is helpful to understand the sense in which the federation's leaders were communists:

We seem to be in some anger of confusing the meaning of 'Communism'. We have in the Sudan two types of Communism: the strictly theoretical and ideological types emanating from the higher schools and the ignorant inferiority complex type emanating from the 'hates and fears fast over taking Africa'. I prefer to call the latter 'revolutionaries'. The former

63 The National Archives of the UK (TNA): Note on Communist Activities in the Sudan, Security, Civil Secretary's office, Khartoum, 4.6.1951, FO 371/90125: 'There is abundant evidence that the communist movement is led by teachers, and in particular those of them in National Schools who have less attractive careers and prospects than their contemporaries in Government service'. See also: Daly (2002, 280) and El-Amin (1996a, 1996b, 1997).

64 The National Archives of the UK (TNA): Extracts from Sudan Weekly Newsletters (Published by Public Relation Branch, Civil Secretary Office, Khartoum, 21.4.1951, FO 371/90125. 
are the real 'Communists'. We have them of course in various walks of life, but particularly as teachers in our schools... The latter type, the 'revolutionaries', are persistently called 'Communists'. I do not think them such unless a definite link is established either in funds or in statements with the former...' ${ }^{65}$

It was of course easy to mistake one communism for the other, and the above remark is one of the rare occasions on which such a distinction was made. The mistake was made easier by the fact that the language of the federation-as expressed, for example, in its statutes - with its strong anti-imperialist tone, appeared to be very radical, and thus similar to, and certainly inspired by, that employed by communists. However, the actual bridge between communist elite politicians and waged workers was an uneasy one, at least in the early 1950s. In 1952, the federation's leaders sought to connect politically with the SMNL. However, the literature reveals that this was a strategic mistake, since union rank and file had little sympathy for the party. Even if more research is needed to understand why workers employed a radical language in labour negotiations, but when it came to vote they supported traditional parties, some hypotheses can be forwarded. The communist-inspired language was listened to very carefully when issues were connected to work. Many workers were employed by British or Europeans; they were experiencing hardship because of an international economy dominated by colonial powers; and they were living their lives in shanty towns where all services were lacking. But, perhaps, when these real-life concerns were expressed by an educated elite that had little or no connection with the life of the workers, it was harder for the workers to trust that elite.

\section{5}

\section{Conclusion}

This chapter has sought to paint a picture of the steps that led to the birth of the workers' movement in Sudan. The re-conceptualisation of the role of the state in development entailed a real redefinition of the negotiating power of the workforce. Using a strategy of confrontation, the latter realised that it could force the state to listen to its demands. In this sense, the development paradigm had an enormous influence on transforming workers into legitimate political actors, for the first time in Sudan's twentieth century history.

65 The National Archives of the UK (TNA): J.W. Robertson to Allen, Khartoum, 15.7.1951, FO 371/90125. 
However, the focus here has been less on who the actors of the movement were and how it worked, than on the relationships and feedback effect between three actors: the Sudanese government, the Labour Party in power in London, and the workers' movement. Because of the centrality of colonial labour debates to the identity and history of the Labour Party, London was determined to introduce labour legislation in Sudan, and subordinated the granting of development funding to the introduction of measures aimed at labour protection. The Sudanese government was very sceptical of this, but was convinced by labour advisors sent from London that it was impossible to stop the march of development. But as events got out of hand, the workers' movement transformed into the worst thing the state had feared it could becomea radicalised movement that struggled to secure the quickest possible end to colonialism.

The curve of the radicalisation of the workers' movement described in this article must not be seen as something inevitable, but as the outcome of a volatile situation. The richness of colonial sources consists precisely in their ability to show how this story was ridden with accidents and evolved in a manner unexpected by all its actors. Such uncertainties, which were kept confidential for fear of losing face with actors that the colonial British officers had no experience of dealing with, emerge clearly from the dense internal correspondence deposited mostly in the National Archives at Kew, London. The Sudanese labour movement was founded by a moderate group whose only previous organisational experience had been to arrange cultural activities in an old boys' club. It is true that the international situation, and in particular the Egyptian example, favoured confrontational attitudes, but as seen, by vocation and ideology the WAA was essentially moderate. And yet its interaction with the state generated a rapid and unplanned transformation, as a consequence of its leaders feeling harassed, maltreated and not taken seriously by the government, and experiencing the state's actions as incomprehensible and unjust.

And in a mirror-like manner, the government hardened its response because it saw the workers' reactions as equally inexplicable: they were ungrateful and unmoved by the government's limitless patience' in teaching them how to run good trade unions. Colonial officers that perceived themselves to be merciful and forgiving, patient and pedagogical, watched with stupor as each of their initiatives triggered more protests. And this in turn provoked self-defeating strategies such as the persecution of trade union leaders, which contributed to a great extent to the success of the movement beyond the wage workers.

Finally, the third unexpected development was the exhaustion of the workers' bellicose strategy. A series of blunders revealed that labour had ceased to 
be at the centre of the preoccupations of union leaders, and that those leaders had lost sight of workers' basic needs. Eventually, a form of consensus emerged through these conflicts, with the elaboration of a status quo that lasted until the end of the 1950s.

\section{References}

Abdel-Rahim, M. (1969) Imperialism and Nationalism in the Sudan: A Study in Constitutional and Political Development, 1899-1956 (Oxford: Clarendon P).

Ali Taha, A.R.E. (1970) 'The Sudanese Labor Movement: A Study of Labor Unionism in a Developing Society', PhD Thesis (Berkeley: University of California).

Beinin, J.Z., and Z. Lockman (1998) Workers on the Nile: Nationalism, Communism, Islam, and the Egyptian Working Class, 1882-1954 (Cairo: American University in Cairo Press).

Berman, B.J. and J.M. Lonsdale (1980) 'Crises of Accumulation, Coercion and the Colonial State: The Development of the Labor Control System in Kenya, 1919-1929', Canadian Journal of African Studies / Revue canadienne des études africaines, 14(1), pp. 37-54, DOI: 10.1080/00083968.1980.10803948.

Bernal, V. (1991) Cultivating Workers: Peasants and Capitalism in a Sudanese Village (New York: Columbia University Press).

Berridge, W.J. (2011) "What the Men Are Crying Out for Is Leadership": The Khartoum Police Strike of 1951 and the Battle for Administrative Control', The Journal of Imperial and Commonwealth History, 39(1), pp. 121-142, DOI: 10.1080/03086534.2011.543797.

Beshir, M.O. (1974) Revolution and Nationalism in the Sudan (New York: Barnes \& Noble Books).

Burton, A. (2003) 'Townsmen in the Making: Social Engineering and Citizenship in Dar Es Salaam, c.1945-1960', The International Journal of African Historical Studies, 36(2), pp. 331-365, http://www.jstor.org/stable/3559387.

Butler, L.J. (1999) 'Reconstruction, Development and the Entrepreneurial State: The British Colonial Model, 1939-51', Contemporary British History, 13(4), pp. 29-55, DOI: 10.1080/13619469908581559.

Constantine, S. (2005) The Making of British Colonial Development Policy 1914-1940 (London: Frank Cass).

Cooper, F. (1996) Decolonization and African Society: The Labor Question in French and British Africa (Cambridge, New York: Cambridge University Press).

Cooper, F. (1992) 'The Dialectics of Decolonization: Nationalism and Labor Movements in Postwar Africa', CRSO Working Paper n. 48o, https://deepblue.lib.umich.edu/bit stream/handle/2027.42/51246/480.pdf?sequence= 1 (accessed on 20 May 2016). 
Cooper, F. and R.M. Packard (1997) International Development and the Social Sciences Essays on the History and Politics of Knowledge (Berkeley: University of California Press).

Corthorn, P. and J.S. Davis (2008) The British Labour Party and the Wider World Domestic Politics, Internationalism and Foreign Policy (London, New York: Tauris Academic Studies).

Cowen, M. and R.W. Shenton (1996) Doctrines of Development (London, New York: Routledge).

Cowen, M. and R.W. Shenton (1991) 'The Origin and Course of Fabian Colonialism in Africa', Journal of Historical Sociology, 4(2), pp. 143-174, DOI: 10.1111/j.1467-6443.1991. tboo101.x.

Cross, P. (1997) 'British Attitudes to Sudanese Labour: The Foreign Office Records as Sources for Social History', British Journal of Middle Eastern Studies, 24(2), pp. 21726o, DOI: 10.1080/13530199708705647.

Curless, G. (2013) 'The Sudan Is "Not Yet Ready for Trade Unions": The Railway Strikes of 1947-1948', The Journal of Imperial and Commonwealth History, 41(5), pp. 804-822, DOI: 10.1080/03086534.2013.790226.

Daly, M.W. (2003) Empire on the Nile: The Anglo-Egyptian Sudan, 1898-1934 (Cambridge, New York: Cambridge University Press).

Daly, M.W. (2002) Imperial Sudan: The Anglo-Egyptian Condominium, 1934-1956 (Cambridge, New York: Cambridge University Press).

Duffield, M.R. and Hewitt V.M. (eds.) (2009) Empire, Development \& Colonialism: The Past in the Present (Woodbridge, Rochester: James Currey).

El-Amin, M.N. (1997) 'The Sudanese Communist Movement, the First Five Years-III', Middle Eastern Studies, 33(1), pp. 128-151, DOI: 10.1080/00263209708701146.

El-Amin, M.N. (1996a) 'The Sudanese Communist Movement, the First Five Years-I', Middle Eastern Studies, 32(3), pp. 22-40, DOI: 10.1080/00263209608701117.

El-Amin, M.N. (1996b) 'The Sudanese Communist Movement; The First Five Years-II', Middle Eastern Studies, 32(4), pp. 251-263, DOI: 10.1080/00263209608701128.

El-Amin, M.N. (1996c) 'The Role of International Communism in the Muslim World and in Egypt and the Sudan', British Journal of Middle Eastern Studies, 23(1), pp. 2953, DOI: 10.1080/13530199608705621.

El-Amin, M.N. (1989) 'International Communism, the Egyptian Wafd Party and the Sudan', British Journal of Middle Eastern Studies, 16(1), pp. 27-48, DOI: 10.1080/13530198908705484.

El-Amin, M.N. (1987) 'The Role of the Egyptian Communists in Introducing the Sudanese to Communism in the 1940s', International Journal of Middle East Studies, 19(4), pp. 433-454.

El-Amin, M.N. (1986) 'The Impact of the Sudanese Unionists on Sudanese Communism', Middle Eastern Studies, 22(3), pp. 418-434, DOI: 10.1080/00263208608700673. 
Fawzi, S. Ed Din (1957) The Labour Movement in the Sudan, 1946-1955 (London, New York: Oxford University Press).

Fawzi, S. Ed Din (1955) 'The Wage Structure and Wage Policy in the Sudan', Sudan Notes and Records, 36(2), pp. 159-175, http://www.jstor.org/stable/41716694.

Freund, B. (1988) The African Worker (Cambridge, New York: Cambridge University Press).

Gaitskell, A. (1959) Gezira; a Story of Development in the Sudan (London: Faber and Faber).

Havinden, M.A. and D. Meredith (2002) Colonialism and Development Britain and Its Tropical Colonies, 1850-196o (London, New York: Routledge).

Hobsbawm, E.J. (1967) 'Trade Union History', The Economic History Review, 2o(2), pp. 358-364, DOI: 10.1111/j.1468-0289.1967.tboo142.x.

Howe, S. (1993) Anticolonialism in British Politics: The Left and the End of Empire, 19181964 (Oxford, New York: Clarendon Press, Oxford University Press).

Howell, D. (1983) British Workers and the Independent Labour Party, 1888-19o6 (Manchester, New York: Manchester University Press; St. Martin's Press).

Lewis, B.A. (1962) 'Deim El Arab and the Beja Stevedores of Port Sudan', Sudan Notes and Records, 43, pp. 16-49, http://www.jstor.org/stable/41716823.

Lewis, J. (2000) Empire State-Building: War \& Welfare in Kenya, 1925-52 (Oxford, Nairobi, Athens, Ohio: James Currey, E.A.E.P., Ohio University Press).

Lilleker, D.G. (2004) Against the Cold War the History and Political Traditions of proSovietism in the British Labour Party 1945-89 (London, New York: I.B. Tauris).

Maul, D. (2012) Human Rights, Development and Decolonization the International Labour Organization, 1940-70 (New York: Palgrave Macmillan).

Orr, C.A. (1966) 'Trade Unionism in Colonial Africa', The Journal of Modern African Studies, 4(1), pp. 65-81, http://www.jstor.org/stable/159416.

Perkins, K.J. (1993) Port Sudan: The Evolution of a Colonial City (Boulder: Westview Press).

Ravier, J.-P. (1981) Les syndicats britanniques sous les gouvernements travaillistes: 19451970 (Lyon: Presses universitaires de Lyon).

al-Safi, Mahasin A. (ed.) (1989) The Nationalist Movement in the Sudan (Khartoum: Institute of African and Asian Studies, University of Khartoum).

Seekings, J. (2011) 'British Colonial Policy, Local Politics, and the Origins of the Mauritian Welfare State, 1936-50', The Journal of African History, 52(02), pp. 157-177, DOI: 10.1017/So021853711000247.

Shane, S. (1989) Trade Union Development in Sub-Saharan Africa (Pretoria: Human Sciences Research Council).

Sharkey, H.J., E. Vezzadini and I. Seri-Hersch (2015) 'Rethinking Sudan Studies: A Post2011 Manifesto', Canadian Journal of African Studies / Revue canadienne des études africaines, 49(1), pp. 1-18, DOI: 10.1080/00o83968.2015.1046256. 
Sikainga A.A. (2002) City of Steel and Fire: A Social History of Atbara, Sudan's Railway Town, 1906-1984 (Portsmouth: Heinemann).

Sikainga A.A. (1996) Slaves into Workers: Emancipation and Labor in Colonial Sudan (Austin: University of Texas Press).

Teelucksingh, J. (2015) Labour and the Decolonization Struggle in Trinidad and Tobago (Basingstoke, New York: Palgrave Macmillan)

Thorpe, A. (2000) 'The Membership of the Communist Party of Great Britain, 19201945', The Historical Journal, 43(03), pp. 777-800, http://journals.cambridge.org/ar ticle_Soo18246X990o1181 (accessed on 20 May 2016).

Thorpe, A. (1998) 'Comintern "Control” of the Communist Party of Great Britain, 192043' English Historical Review, 113(482), pp. 637-662, DOI: 10.1093/ehr/CXIII.452.637.

Thorpe, A. (1997) A History of the British Labour Party (New York: St. Martin's Press).

Tijani, H.I. (2012) Union Education in Nigeria: Labor, Empire, and Decolonization since 1945 (Basingstoke: Palgrave Macmillan).

Vatikiotis, P.J. (1969) The Modern History of Egypt (New York: Praeger).

Vezzadini, E. (2015) Lost Nationalism: Revolution, Memory and Anti-Colonial Resistance in Sudan (Woodbridge, Rochester: James Currey).

Vezzadini, E. (2010) 'Making the Sudanese: Slavery Policies and Hegemony Construction in Early Colonial Sudan' in J. Spaulding, S. Beswick, C. Fluehr-Lobban and R. Lobban (eds.) Sudan's Wars and Peace Agreements (Newcastle upon Tyne: Cambridge Scholars Publishing), pp. 71-101.

Vickers, R. (2004) The Labour Party and the World (Manchester, New York: Manchester University Press).

Warburg, G.R. (1978) Islam, Nationalism and Communism in a Traditional Society: The Case of Sudan (London: F. Cass).

Weiler, P. (1984) 'Forming Responsible Trade Unions: The Colonial Office, Colonial Labor, and the Trades Union Congress', Radical History Review, (28-30), pp. 367-392, DOI: 10.1215/01636545-1984-28-30-367.

Worley, M. (2005) Labour inside the Gate: a History of the British Labour Party between the Wars (London, New York: I.B. Tauris).

Zeilig, L. (2009) Class Struggle and Resistance in Africa (Chicago: Haymarket Books). 